DOI: $10.21625 /$ archive.v2i2.248

\title{
A Study on Cultural Sustainable Tourism in Context of Painted Scrolls
}

\author{
Kanak Lata Singh ${ }^{1}$ \\ Assistant Curator, Painting National Museum, New Delhi, India
}

\section{Keywords}

Art, Heritage, Tourism.

\begin{abstract}
India is known for its reach in Art and Culture. Cultural tourism provides a major contribution to the development of the country from different aspects. Apart from supporting the Indian economy, cultural tourism also helps in preserving and developing unique art traditions which are slowly dying out due to negligence.

patachitra, the painted scroll of Bengal is one of them. The patachitra tradition is an essential part of intangible heritage based on tour practices. Patuas, as they are known as a community, chiefly represent a group of artists wandering with their painted scrolls and narrating the stories from place to place to earn their livelihood. The patachitra is a platform where several mediums of communication are united such as visual messages, oral traditions and music during process of storytelling. These painted scrolls represent narration of Hindu mythologies as well as folklore.

In this regard, considering business as one of the purposes of tour, this research about patua artists working for patachitra in West Bengal is an attempt to reveal the fact that artifacts, as a part of culture, and tourism are two sides of the same coin. The existence of one is essential for the survival of the other.
\end{abstract}

\section{Introduction}

In the context of cultural sustainable tourism and the painted scrolls of the West Bengal, this article attempts to present a study that reveals how cultural sustainable tourism helps in preserving and developing unique and traditional art forms that are slowly dying due to negligence. It also highlights that local art forms of the country that strongly attract tourists and play a significant role in cultural tourism and developing the tourism market in India.

Culture is a combination of different activities and ideas of a group of people with shared traditions, which are transmitted and reinforced by members of the group. New research reveal that "Culture refers to the cumulative deposit of knowledge, experience, beliefs, values, attitudes, meanings, hierarchies, religion, notions of time, roles, spatial relations, concepts of the universe, and material objects and possessions acquired by a group of people in the course of generations through individual and group striving".

During this era of globalization in the industry of tourism, a new section of cultural tourism emerged in the 20th century. Cultural tourism not only pushed the market of tourism and the economic condition of country forward, but also created a curiosity on a global level towards gathering knowledge about art and culture of different parts of the world. Cultural tourism can be defined as "that activity which enables people to experience the different ways of life of other people, thereby gaining a firsthand an understanding of their customs, traditions, the physical environment, the intellectual ideas and those places of architectural, historic, archaeological or other cultural significance which remain from earlier times. Cultural tourism differs from recreational tourism in that it seeks to gain an understanding or appreciation of the nature of the place being visited. "

\section{Correlation between Cultural Tourism, Art and Culture:}


Incorporating arts and culture into the tourism product helps to create a distinct image and identity of the visited place, which is important for a country to project itself. Considering culture and the arts as an integral part of the tourism product helps to preserve local identities and protect cultural experiences. In many instances, it encourages the realization and recovery of local cultural resources that we either forgot about or do not even know existed.

Cultural tourism provides an opportunity to make smaller communities more attractive. It creates vibrant spaces in small neighborhoods, expand business opportunities and improve the quality of life.

An analysis of the extent of tourist involvement in the cultural tourism industry and their level of involvement in culture are art is presented in the following table.

Table 1: Type of Cultural Tourism and Level of involvement of Tourists

\begin{tabular}{|l|l|}
\hline Type of Cultural Tourist & Level of Involvement of Tourist \\
\hline The purposeful cultural tourist & $\begin{array}{l}\text { Cultural tourism is the primary motivation for visiting a destination and the } \\
\text { tourist has a very deep and elaborate cultural experience }\end{array}$ \\
\hline The sightseeing cultural tourist & $\begin{array}{l}\text { Cultural tourism is a primary reason for visiting a destination, but the } \\
\text { experience is less deep and elaborated }\end{array}$ \\
\hline The serendipitous cultural tourist & $\begin{array}{l}\text { A tourist who does not travel for cultural reasons, but who, after } \\
\text { participating, endsup having a deep cultural tourism experience }\end{array}$ \\
\hline The casual cultural tourist & $\begin{array}{l}\text { Cultural tourism is a weak motive for travel and the resulting experience is } \\
\text { shallow }\end{array}$ \\
\hline The incidental cultural tourist & $\begin{array}{l}\text { This tourist does not travel for cultural reasons, but nonetheless participates } \\
\text { in some activities and has shallow experiences }\end{array}$ \\
\hline
\end{tabular}

As per the aforementioned chart, the first two groups of tourists show that they are intentionally involved in cultural tourism and thus are deeply influenced by it. The third group of tourists reveals that even if a tourist does not travel for cultural reasons, he or she may be deeply influenced by the art and culture of the visited area. The last two groups are such tourists who are only casually and incidentally involved in art and culture of the visited area.

The presented study shows that, directly or indirectly, partially or fully, the tourist is always influenced by the art and culture of the visited area. This way, local art and culture contribute a lot to development of tourist footfalls in the visited area.

Not only do tourists get influenced by the visited area, but the area itself is is definitely influenced by the tourists. These influences can be positive or negative and they are presented in the following table.

\begin{tabular}{|l|l|}
\multicolumn{2}{|l}{ Table 2: Positive and negative effects/impacts of cultural tourism } \\
\hline Positive effects & Negative effects \\
\hline The development of the regional culture & Culture become commercialized \\
\hline Protection of the natural habitat & Destruction of the environment \\
\hline The accentuation of tourism regions & $\begin{array}{l}\text { Investments in tourism that act } \\
\text { against the state of the environment }\end{array}$ \\
\hline Strengthening of the local traditions and culture & $\begin{array}{l}\text { Architecture not characteristic to the } \\
\text { local customs }\end{array}$ \\
\hline Less seasonal, can extend the tourism season & Carrying capacity problems \\
\hline Can be an important form of sustainable tourism & $\begin{array}{l}\text { Cultural tourism has only a } \\
\text { dependent role (need for package) }\end{array}$ \\
\hline & Conflict source \\
\hline
\end{tabular}

The table above shows that cultural tourism has a greater positive effect on art, culture and life of common people. It spreads more awareness of the place's values, languages, lifestyle, and customs. By maintaining 
awareness about the importance of cultural tourism and the everlasting positive effects it has, a country can create a balance between the society, environment, and tourism for improving the economic condition of the country.

In this regard, a detailed study about Painted scroll of the West Bengal (Kalighal pata Painting) and role of tourism in preserving and developing this folk art form is being presented here. It is also important to discuss the contribution of this painted scroll to the development of cultural tourism as well. Any static data of tourist flow in West Bengal has not been used for analyzing the contribution of cultural tourism in the existence and development of the tradition of painted scroll as it is not available because the school of painted scroll was originated in the early 19th century and at that time, study about tourism in India had not started.

\section{Painted scrolls of the West Bengal:}

West Bengal is a state situated in the eastern part of India, which shares its international border with Bangladesh, Nepal and Bhutan. Some of the important tourist centers are Calcutta, Tarakeswar (pilgrim centre), Shantiniketan (work place of Rabindranath Tagore), Bakreshwar (pilgrim centre) at Birbhum district, Durgapur (industrial city) and Dakhineshwar kali Temple, Kalighat.

Painted scroll is one of the major tourist attractions in terms of artifacts and its famously known as Kalighat Pata Painting. This article states that because of the increasing number of tourists in colonial India, this folk art form of painted scrolls has taken a new turn and reached its fully developed form.

The tradition of painted scroll was originated by the hereditary painters of the eastern Indian region of Bengal. Initially, the artists were wandering in one place and the other with painted scroll but in early 19th century, they settled down in Kalighat. Kalighat pata painting is considered as a folk art tradition. Ajit Ghose said "The word 'Pata' is a Sansakrit word of considerable antiquity which has posed into the Bengalee language. It has a double denotation (i) a beautiful cloth and (ii) a picture painted on cloth ...." .

The scroll painters illustrate narration of stories in a chronological way on handmade paper coated on cloth. Artists use mineral and organic colors. The width of scroll painting can go from 4 to 14 inches and their length can be 3 to 15 feet. A piece of bamboo is placed on each end of the scroll and it is used to roll the painted scroll.

The artists use these painted scrolls for presenting stories through visual depiction by evoking responses from their audience. The performance of patua songs assisted by scenes displayed from their scrolls. The songs consist of rhymed couplets, one or more corresponding to each register of the pata. As a song unfolds, the patua unwinds the scroll to the appropriate scene displaying the relevant pata skillfully with the help of bamboo handles at either end of the long scroll. This gives these scrolls their name, jorano pata (rolled scroll), to distinguish them from square ones depicting single scenes. These itinerant entertainers travel from village to village performing stories in public spaces such as the bazaar or the courtyards of schools, temples, or large homes. It is not uncommon to run into a crowd gathered under the shade of a banyan tree, mesmerized by the patua's performance.

The scroll painting of Kalighat originated as a tool of entertainment for common people. In return for their services, they were paid in cash. These painted scrolls are a source of livelihood of patuas, thus, they worship it before starting performances and on special occasions at their homes.

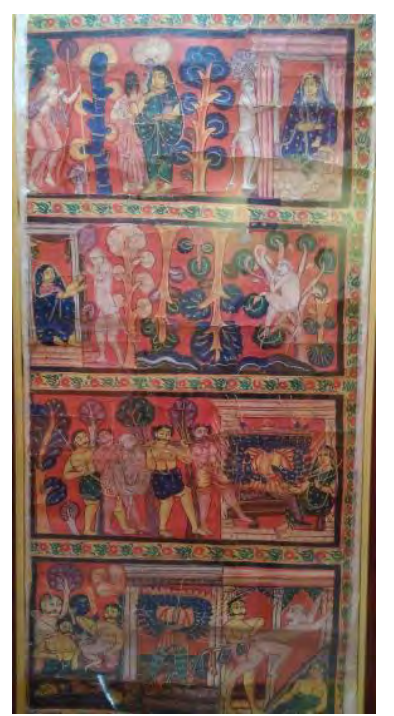

Figure 1 Ramayana Pata West Bengal, $20^{\text {th }}$ Century, Cloth National Museum, New Delhi 
The initial major subject of these scroll paintings were narration of mythological stories as Ramayana, Mahabharata, some stories from Bhagawat Purana. A beautiful example of scroll painting titled as 'Ramayana Pata' (Figure1) illustrated with scene from Ramayana series, made in late twentieth century is in collection of the National Museum, New Delhi. The top most panel shows the scene of Balli and Sugriv's combat followed by other scenes depicting (Figure 2) Hanumana and wife of legendary hero prince Rama Sita's plight as a captive in Ravana's Ashok Vatika

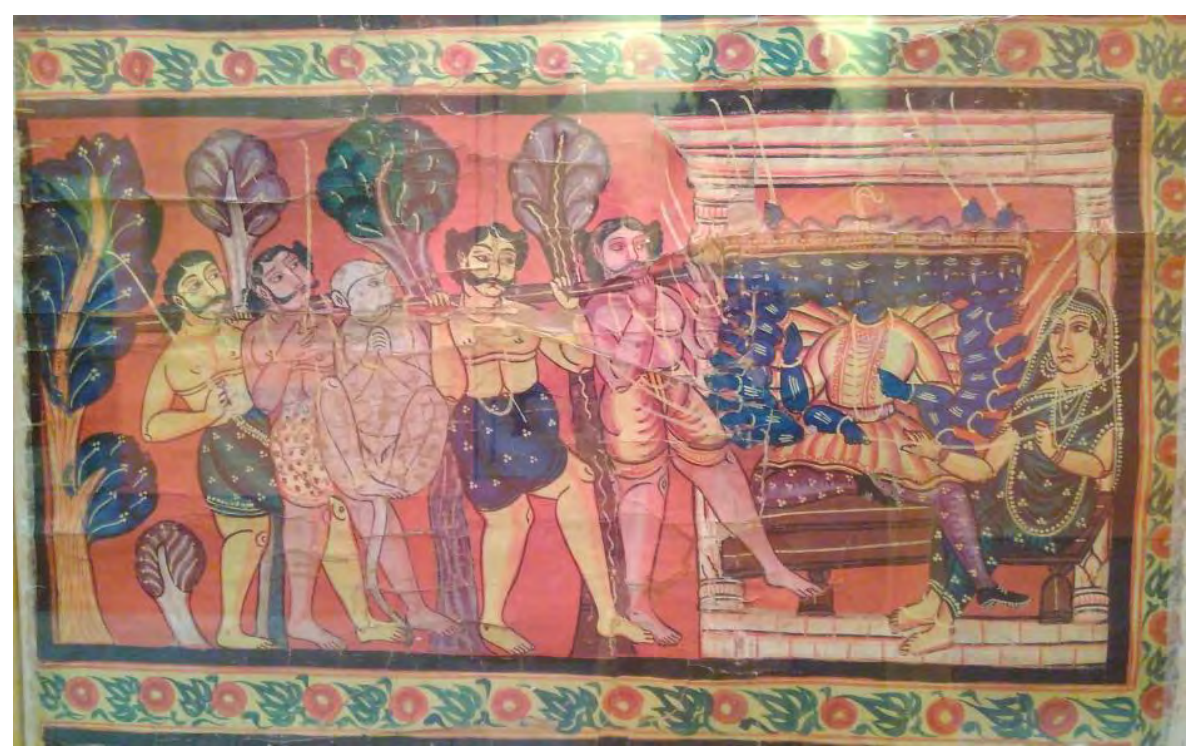

Figure 2, Close up of the Ramayana pata, National Museum, New Delhi

Before Kalighat, Chitpur near the temple of Chitteshwari founded in 1610 CE was a major centre for religious purposes and of tradition of painted scroll. Chitpur was infested with dacoits area therefore after the establishment of Kalighat temple in 1809 CE a number of artists migrated from Chitpur, Nabadwip, Krishnanagar, Mituri and Shantipur to Kalighat. In the early 19th century, Kalighat became a popular pilgrimage centre. Due to the name of temple Kali the painting tradition which was developed around this temple has been called Kalighat painting. Here it's clear that due to the increasing number of domestic tourists coming for religious purposes, art of painted scroll shifted to Kalighat, West Bengal.

In time, several new themes like historical stories, folklore and contemporary scenes of social issues became popular subjects of the painted scrolls. The reason behind this change was the migrating interest of the public for which these paintings were made. Early 19th century was a period when the Indian freedom struggle was in its peak and in order to achieve political freedom from the British rule, everyday new movements were run by the Indian political leaders. These political movements were strongly influenced by the life of common people such as under Swadeshi movement (1905 CE) based on the request of Indian political leaders' common public to completely boycott goods imported into the Indian market from England. The patua artists played a significant role to make people aware of these kinds of facts related to the national freedom struggle through the painted scrolls. Even the common public was taking more interest in hearing stories of freedom movements than old mythological stories. It was the first major change in the art of painted scroll which emerged due to political issues.

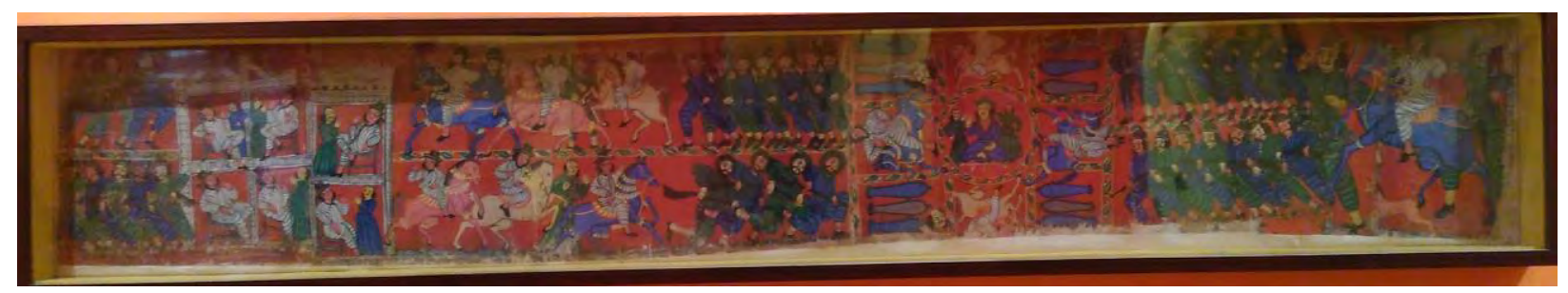

One of the examples of Kalighat scroll painting is related to the freedom struggle movement of 'Saheb Pat' (Figure 3). In the present pat painting the whole story is chronologically narrated into small sections and each part is divided by lines. In one section, British officers are seen making a plan of war with freedom fighters and in another one, they are shown fighting with freedom strugglers. (Figure 4) Human figures are made with puppet 
type eyes and tubular body limbs as we find in painted terracotta of Kalighat because many clay figure modelers or potters were working as patua painters in Kalighat as well as at other centers of Kolkata.

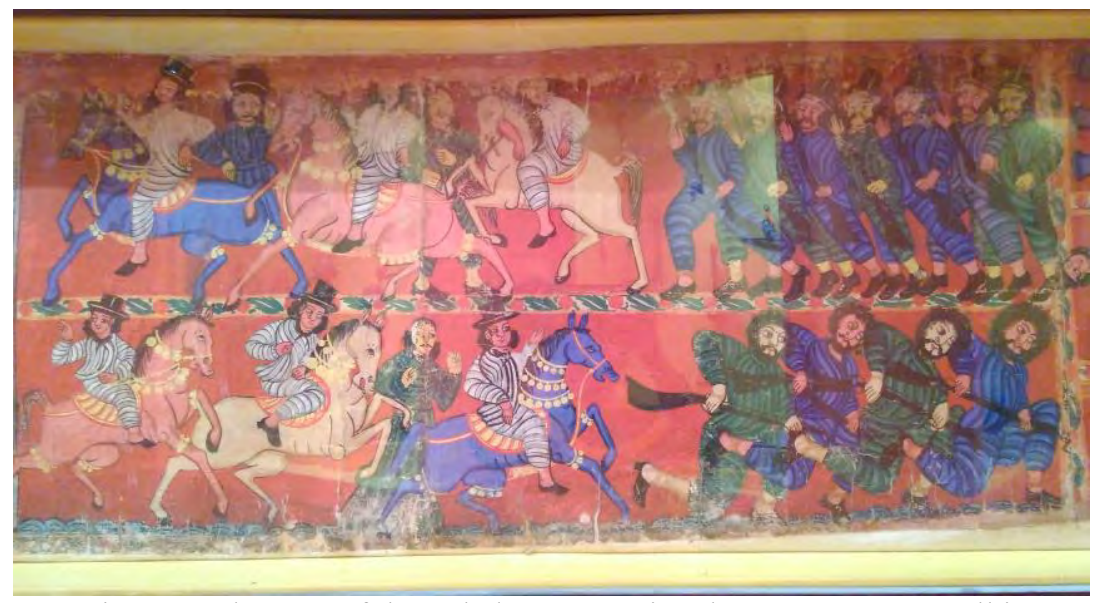

Figure 4, close up of the Saheb Pata, National museum, New Delhi.

Due to increasing mediums of entertainment like movies, dance and drama, the tradition of telling stories by pata (scroll) paintings started decreasing rapidly in the middle of the 19th century. At present in villages of West Bengal this tradition is rarely being performed by the patua artist. As this painting tradition was a medium of earning livelihood for the pauta Painters they adopted new elements to keep it in demand of tourists and art appreciators.

The embracing of European expressive forms in the region's cultural life in the late nineteenth century affected the traditional artistic practice of Kalighat painting in a variety of ways. Artists used opaque water color style from the British for the Kalighat Painting. Unique handling of the pictorial form and adaptation of the dramatic costumes such as boots, hats, props and instruments like violin for Hindu deities were major elements that emerged in this Indian paintings school. It was considered a depiction of westernization in Indian art. As a result, new themes, stylistic features, and even the paper was also introduced as a new surface of painting at the place of scroll. After that, along with Painting of Company Schools, the tourists and British officers as well started to carry out Kalighat Paper Paintings as souvenirs for their homes.

As a result, a new genre of Kalighat paper painting emerged in the second half of the nineteenth century from the resourceful adaptation of traditional scroll paintings of Kalighat. In the paintings made on paper, the artists left the background blank but in the scroll paintings background are full of trees, ponds, rivers and vases according to the requirement of the theme.

It again reveals that due to presence of a number of tourist and the presence of Indians and British officers and their relatives, folk painting trend of Kalighat school was highly influenced and it took a new turn. The Kalighat Painting School was an outcome of new lifestyle and aesthetic norms with shifting standard of morality. As Jyotindra Jain said that "The story of Kalighat painting is the story of the transformation of folk art form into a popular genre of robust encounter of rural artists who migrated to the city of Calcutta "

Some important artists of Kalighat painting school were Nirban Chandra Ghose, Kali Charan Ghose, Nilmani Das, Balram Das Prabin Chandra, Inanendra Patidar, Khandu, Dhiren and Paritosh and Gopal Das. Ajit Mukherjee said that later Kalighat paintings reveal influence of British water color but according to W.G. Archer, there is no evidence that any painter received training from British tutors.

The Kalighat paintings are both time-and-space-bound. Thus, they reflected the time and place in which they were created. The Kalighat paintings were the first true caricature and satirical artists of India. Around 1920 CE, Kalighat painting trend had spread to Paharpur, Tollyguna in Kolkata, Mahesh Ballavapura and Panrojtala in Hawrah and 24 Paragana.

\section{Role of cultural tourism in existence and development of Painted Scroll in the West Bengal:}

The art of painted scroll known as Kalighat Pata Painting or patachitra is an essential part of intangible heritage based on tour practices of the Patuas or the artists who make patachitras. Patuas are known as a community made up of a group of artists wandering with their painted scrolls from place to place to earn their livelihood through storytelling. Therefore, tour practice is considered as one of the major causes of the origination of the art form in West Bengal. 
When the centre of the traditional art school shifted from Chitpur to surrounding areas of the Kalighat Kali temple, the increasing number of Indian pilgrims' demand for these painted scrolls reached its peak. Here again it seems that due to the increasing number of domestic tourists the art of painted scrolls matured in West Bengal. In this regard, Jyotindra Jain said that Calcutta was a major trade centre of India in colonial period thus 'between 1854 to 1877 Howrah station of Kolkata was connected with the national railway network. It was linked to main cities of India like Varanasi, Allahabad, Patna, Mumbai and Agra etc. Therefore, a large number of visitors have been coming here every year. These visitors desired to carry home typical and easily portable souvenirs such scroll paintings. Indian foreign tourists also prefer to carry out painted scrolls as souvenirs to their homes. Thus the folk painting of Kalighat became the center of attraction for foreign people.

Based on the aforementioned, it's proven that cultural tourism protected and strengthened the local tradition of painted scrolls.

\section{Role of Painted scroll and other art forms in existence and development of cultural tourism in the West Bengal:}

It has already been discussed under the title of correlation between art, culture and tourism that directly or indirectly tourists are always influenced by the art and culture of the visited area. The culture tourism extends more consciousness about a place's values, languages, lifestyle, and customs into the visitors. This is how it plays a significant role in the development of tourist footfalls in the visited area.

Regarding the contribution of art and culture in Cultural tourism, H.L. Hughes said that Growth in travel opportunities and improved communication systems has contributed to an increased awareness of global culture. Consumers are now familiar with the art and music of many other countries besides their own. It is natural that they would want to visit cultural organizations to experience these art forms when they travel. Heritage sites and museums, along with theatres and other performing arts venues, are a significant reason why tourists visit the major urban areas.

In the above lines Hughes discussed about contribution of tourism that how it make aware people of the other country about art and culture of the one nation which develop interest of people to visit that country and know more about art and culture. Similarly in colonial India the British officer had come initially for trading and later for ruling then they desired to know more about Indian life and culture. As a result they attracted towards art and culture and given their contribution in preserving it.

The same had happened in the case of painted scroll of the Kalighal, West Bengal. The tradition of painted scroll was originated as tool of entertainment for the common people of West Bengal and as medium of livelihood for the Patua community. The School of painted scroll reached on its peak in Kalighat due to increasing number of pilgrim or domestic and British tourists in West Bengal during colonial period. The Indian people contributed in stylistic and theme based changes in this art form whereas reasons for suddenly increasing demand of the Kalighat paintings were the British officers who chosen Kalighat Paintings to carry out as souvenir to their homes. The tradition of this art form is still contributing a lot in attracting eyes of international and domestic tourists as an important tourist product.

For tracing tourist flow in colonial India static data is not available but for analyzing contribution of art and culture in increasing number of tourist flow and contribution of tourisn in Indian economics in present era a static data is presented herewith.

Through statics data about increasing footfalls in West Bengal State tourism minister Bratya Basu said West Bengal in 2014 saw around 89\% growth in tourist footfall as compared to the previous year 2013, 5.04 crore tourists visited Bengal last year compared to 2.67 crore in 2013. Apart from the overall growth, number of foreign tourists also went up to 14 lakh from 12.45 lakh in 2013. In 2011-12 the allocation was Rs 44 crore which has gone up to Rs 317 crore in 2015-16.

Table 3: Year-wise growth of tourist footfall in Bengal

\begin{tabular}{|c|c|c|}
\hline Year & Domestic Tourists (crore) & Foreign Tourists (lakh) \\
\hline 2010 & 2.0 & 11 \\
\hline 2011 & 2.22 & 12.01 \\
\hline 2012 & 2.40 & 12.18 \\
\hline 2013 & 2.55 & 12.45 \\
\hline 2014 & 4.90 & 14 \\
\hline
\end{tabular}


West Bengal improved its position among the States, moving up to fifth, with 1.49 million foreign tourists visiting the State in 2015.

Indian tourism industry has gone to new height in recent times. Both tourist arrival as well as revenue earned thereof are showing a steep hike. As per the World Travel and Tourism Council estimate, this sector now generate more than $4 \%$ of the country's GDP and more than 20 crore jobs

The Tourism Ministry has also played an important role in the development of the industry, initiating advertising campaigns such as the 'Incredible India' campaign, which promoted India's culture and tourist attractions in a fresh and memorable way. The campaign helped create a colorful image of India in the minds of consumers all over the world, and has directly led to an increase in the interest among tourists. p 240

The present study reveals that painted scroll in Kalighat has been playing an essential role in the tourism flow in the West Bengal since colonial period.

\section{Conclusion}

India is known for its rich art and culture thus a number of foreign tourists come here for cultural tourism. Summarizing this article, it is submitted that the cultural tourism product like art, heritage etc. and cultural tourism itself is a very important part of the Indian culture and economy. In order to enhance the Indian economic condition, the government also supports tourism in India. Through the present study about cultural sustainable tourism and the painted scrolls of the West Bengal, the following facts came to light:

1. Existence of Cultural tourism is dependent on the availability of art and culture of the Country as art and culture are two important tourism products.

2. The art of painted scroll of Kalighat is one of the major tourist attractions of India.

3. Culture Tourism protected and strengthened the local tradition of Painted scrolls in West Bengal as domestic and foreign tourists in colonial India were responsible for the stylistic changes considered as development in this art of painted scroll.

It's now proven that the existence of cultural tourism depends on the existence of folk art and vice versa.

\section{References:}

1. G. Hofstede, Cultures and Organizations: Software of the mind, (McGraw, New York: 1997), 279.

2. International Scientific Committee on Cultural Tourism, Charter for Cultural Tourism (1997, http://www.icomos.org/tourism)

3. Pika Ghose, Unrolling a Narrative Scroll: Artistic Practice and Identity in Late-Nineteenth-Century Bengal (The Journal of Asian Studies, Vol. 62, No. 3 , 2003), 840 Ibid: p. 844

4. Jyotindra Jain, Kalighat Painting Images from Changing World (Mapin Publishing Ltd. Ahmadabad:1999) 40 Ibid, 5: p. 9

5. W.G. Archer, Bazar Paintings of Calcutta : The style of Kalighat (Her Majesty's Stationery Office, London :1953) 8 Ibid 5: p.13

6. H.L. Hughes ,"Urban Tourism and the Performing Arts” Quality Management in Urban Tourism, Wiley ( source: http://aitcofficial.org/aitc/west-bengal-registers-positive-growth-in-tourism-says-national-report/ New York, 1997)

7. Anonymous, Bengal tourism flourishes - tourist footfall doubles in 2014 (May 22, 2015, http://aitcofficial.org/aitc/bengal-tourism-flourishes-tourist-footfall-doubles-in-2014/). Ibdi 9.

8. ${ }^{1}$ Sherap Bhutia, Growth \& Development of Tourism Sector in West Bengal: Issues \& Concerns (American International Journal of Research in Humanities, Arts and Social Sciences Available online at http://www.iasir.net) 